\title{
Preliminary results of radon survey in thermal spas in V4 countries
}

\author{
Monika Múllerová, \\ Jadwiga Mazur, \\ Pavol Blahušiak, \\ Dominik Grządziel, \\ Karol Holý, \\ Tibor Kovács, \\ Krzysztof Kozak, \\ Erika Nagy, \\ Martin Neznal, \\ Matej Neznal, \\ Amin Shahrokhi
}

\begin{abstract}
Radon concentration was measured in 11 thermal spas in Visegrad countries (Czech Republic, Hungary, Poland, and Slovakia). The results showed that in $84 \%$ of spas radon activity concentration is less than $400 \mathrm{~Bq} \cdot \mathrm{m}^{-3}$. However, areas with radon activity concentration exceeding $1000 \mathrm{~Bq} \cdot \mathrm{m}^{-3}$ were found in the Czech Republic and Slovakia as well. Preliminary analyses indicated that the highest radon activities in spas were found in places with thermal pools. Radon concentration in waters used in spas ranged from $0.5 \mathrm{~Bq} / \mathrm{l}$ to $384 \mathrm{~Bq} / \mathrm{l}$. The influence of radon activity concentration in water on radon activity in the air inside the spa was observed. It was found to increase indoor radon with increasing radon in the waters. Correlation with indoor radon and radon in water was more significant for baths and less significant for pool waters. In the cases filling of the bath from water taps, significantly contribute to the increased radon was observed in the pool and bath areas of the spa.
\end{abstract}

Key words: indoor radon • thermal spas • thermal water

M. Múllerová ${ }^{\bowtie}$, P. Blahušiak, K. Holý

Department of Nuclear Physics and Biophysics,

Faculty of Mathematics, Physics and Informatics,

Comenius University,

Mlynská dolina F-1, 84104 Bratislava,

Slovak Republic,

Tel.: +421 260295 451, Fax: +421265412 305,

E-mail: Monika.Mullerova@fmph.uniba.sk

J. Mazur, D. Grządziel, K. Kozak

Laboratory of Radiometric Expertise,

Institute of Nuclear Physics PAN (IFJ PAN),

152 Radzikowskiego Str., 31-342 Krakow, Poland

T. Kovács, E. Nagy, A. Shahrokhi

Institute of Radiochemistry and Radioecology,

University of Pannonia,

Egyetem u. 10, H-8200 Veszprém, Hungary

M. Neznal, M. Neznal

RADON v.o.s.,

Novakovych 6, 18000 Praha 8, Czech Republic

Received: 16 December 2015

Accepted: 31 March 2016

\section{Introduction}

Radon $\left({ }^{222} \mathrm{Rn}\right)$ activity concentrations in thermal waters, consequently also in spas, differ in a rather wide range. In general, the main source of radon in thermal baths is the thermal water, which comes from deep springs, and this can contain high radon concentrations which accumulate in those areas in which therapy is carried out. ${ }^{222} \mathrm{Rn}$ concentrations in some thermal waters can exceed $1000 \mathrm{~Bq} / \mathrm{l}$ [1]. The use of thermal water in the balneotherapy process contributes to radon release from the water into the indoor air of the workplace. Radon activity concentration can reach high values due to large volumes of water used. In spas, the professional staff are exposed for a longer time than visitors and effective doses they get may vary - from several units to tens $\mathrm{mSv}$ per year $[2,3]$.

Several radon surveys in spas were performed in Europe to assess the indoor radon levels and radon exposure. Radon measurements in thermal waters of Lądek Zdrój in Poland showed values from $122 \mathrm{~Bq} / \mathrm{l}$ to $1284 \mathrm{~Bq} / \mathrm{l}$ [4]. Radon concentrations of thermal waters in the spas of Lesvos Island in Greece were found in the range 10 and $304 \mathrm{~Bq} / 1$ [5]. Radon measurements in the air and thermal water of nine Croatian spas were performed and radon concentrations in the air and water of the swimming pools were obtained in the range of $10.9-109 \mathrm{~Bq} \cdot \mathrm{m}^{-3}$ and 0.73-18.6 Bq/1, respectively [6]. Radon measurement in five Slovenian spas was carried out. Indoor radon was obtained in the range of $15-279 \mathrm{~Bq} \cdot \mathrm{m}^{-3}$ 
[7]. Measurements of indoor radon concentration in air and in water in spas are carried out in Niška Banja in Serbia [8] and in Jáchymov in the Czech Republic [9]. In the Niška Banja spa, the radon concentrations in the air and in water were obtained in the range of $140-2810 \mathrm{~Bq} \cdot \mathrm{m}^{-3}$ and $24.5-648 \mathrm{~Bq} / \mathrm{l}$, respectively [8]. In Jáchymov, the results showed indoor radon concentration up to $8951 \mathrm{~Bq} \cdot \mathrm{m}^{-3}$ and radon in water was $6725 \mathrm{~Bq} / \mathrm{l}$ [9].

In Visegrad (V4) countries (Czech Republic, Hungary, Poland and Slovakia), there is a long tradition of using thermal waters in the spa treatment. In the framework of the Visegrad Fund, the project "Radon in thermal waters and radon risk in chosen thermal water spas in V4 countries" has been carried out. The aims of the project were the study of radon concentration in selected thermal waters and thermal spas in V4 countries, to get information about radon seasonal variations and to evaluate the effective dose from radon inhalation for spas-workers. Indoor radon has been measured using passive track detectors (RAMARN). The rooms have been chosen for radon measurements: a balneotherapy room, a room with a pool and a physician office. The survey lasted for one year. This paper presents the preliminary results of the survey performed for 3 months; from March to May 2014. Effective dose for staff and visitors will be calculated in further studies.

\section{Localities of measurements and methods}

Each participant in the project selected several spas in their own country for indoor radon and radon concentration in water monitoring. The survey was performed in three spas in Hungary and the same in Poland, in one spa in Czech Republic and four spas in Slovakia. Totally radon was measured in 11 spas.
Each spa was of different dimension; the number of the buildings with a spa procedure: some spa was situated in one building, other spa in two or three buildings; size of individual rooms and the age of the buildings: some buildings were built in the 13th and 17 th centuries, majority buildings in the 19th and 20 th centuries. Indoor radon levels were measured using passive track detectors RAMARN. The detectors were exposed for 3 months. The RAMARN detector (National Institute for Nuclear, Chemical and Biological Protection, Czech Republic) consists of a plastic diffusion chamber that is conical cylindrical in shape and about 0.5 litre in volume. A bare Kodak LR 115 film is located at the bottom of the diffusion chamber. The size was chosen to avoid the influence of deposited decay products from radon. The tracks are visualized on LR-115 film only for alphas with energies between 1 and $3 \mathrm{MeV}$ that touch the foil; thus the effective volume has a lens shape [10].

The determination of radon in thermal waters, which are used in spas, was also carried out. Each country measured radon in water samples by their own methods (Table 1). However, an international intercomparison measurement of radon in water samples taken from a selected spa was realized [11].

\section{Results and discussion}

In the first period of radon monitoring in spas (from March to May 2014) high differences in measured values of indoor radon activity concentration in the air among V4 countries were found. The frequency distribution of indoor radon air levels in spas is depicted in Fig. 1.

In the majority of investigated rooms (56.4\%) the indoor radon concentration was less than $200 \mathrm{~Bq} \cdot \mathrm{m}^{-3}$. In $27.3 \%$ of rooms, radon concentration

Table 1. Sampling and measuring methods

\begin{tabular}{|c|c|}
\hline Country & Methods of radon in water measurement \\
\hline $\begin{array}{l}\text { Czech } \\
\text { Republic }\end{array}$ & $\begin{array}{l}\text { Water sample is collected into a pre-evacuated glass cell }(125 \mathrm{ml}) \text { with a rubber stopper using a } \\
\text { needle; radon from the glass cell is transferred into a pre-evacuated glass-type Lucas cell }(600 \mathrm{ml}) \text {; } \\
\text { Lucas cells measured in scintillometer (LUK 1, LUK 4A); counting in equilibrium (more than } 3.5 \mathrm{~h} \\
\text { after the transfer; } 400 \mathrm{~s}) \text {. }\end{array}$ \\
\hline Poland & $\begin{array}{l}\text { Ionization chamber method (ICH): } \\
500 \mathrm{ml} \text { of the sample is transferred to the degassing vessel - radon is expelled from the water sample } \\
\text { by the AlphaPUMP in a closed gas cycle; radon concentration in air is measured in the ionization } \\
\text { chamber of AlphaGUARD PQ2000PRO. } \\
\text { Liquid scintillation counting (LSC): } \\
\text { water sample is transferred directly from the source to the } 20 \mathrm{ml} \text { glass vial with scintillator, using } \\
\text { special glass pipette; water sample in the vial with scintillator is closed and mixed for a few minutes } \\
\text { to extract radon from water to the scintillator; counting in equilibrium; vials are measured in liquid } \\
\text { scintillation counter ( } 30 \text { min). }\end{array}$ \\
\hline Hungary & $\begin{array}{l}\text { Radon from the } 100 \mathrm{ml} \text { sample is transferred by nitrogen (10 min) to a } 300 \text { A Pylon scintillation cell } \\
(270 \mathrm{ml}) \text {; Pylon AB-5 with a 300A Pylon scintillation cell and Pylon WG1001 degassing system. }\end{array}$ \\
\hline Slovakia & $\begin{array}{l}\text { Before the measurement } 7 \mathrm{ml} \text { of the water sample is transferred to the degassing vessel by using a } \\
\text { burette; quantitative vacuum method is used for the transport of radon from degassing vessel to the } \\
\text { Lucas cell }(125 \mathrm{ml}) \text {; Lucas cell (brass cylindrical vessels with the flat glass bottom, produced by } \\
\text { EMPOS Praha, CZ); for counting, the chambers are connected with scintillation probe and electron- } \\
\text { ics in CAMAC standard; counting in equilibrium (more than } 3.5 \mathrm{~h} \text { after the transfer). }\end{array}$ \\
\hline
\end{tabular}




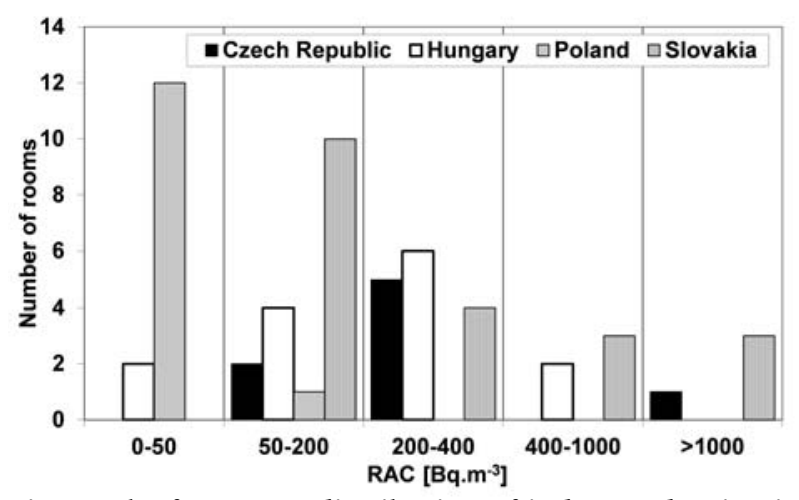

Fig. 1. The frequency distribution of indoor radon in air concentration in the spas in V4 countries.

varied between 200 and $400 \mathrm{~Bq} \cdot \mathrm{m}^{-3}$. Indoor radon concentration in $16.4 \%$ cases exceeded $400 \mathrm{~Bq} \cdot \mathrm{m}^{-3}$, what is the reference value of work places recommended in legislation in V4 countries. The highest measured indoor radon activity was approximately $12000 \mathrm{~Bq} \cdot \mathrm{m}^{-3}$.

In general, for measuring spas in V4 countries, the highest indoor radon level was observed in the pool areas (Fig. 2). However, relatively increased radon levels were also found in dressing rooms for the spa staff. For example, in one Slovak spa, radon levels were observed 460 and $8100 \mathrm{~Bq} \cdot \mathrm{m}^{-3}$ in two staff's rooms. The increased radon activity concentration in the air of this type of rooms can be explained by the age of the buildings and related building construction and ventilation system and conditions, moreover these rooms were often situated nearby the pool areas.

An international intercomparison measurement of radon in water using different instruments and methods was realized in Czech spa [11]. The first intercomparison measurements showed some variability results, although all values fell within three standard deviations. Differences of reported values were probably caused by differences in the primary calibration, but partly too not simultaneously sampling; sampling from different depths below the free water level and from an inhomogeneous distribution of radon in the water in reservoirs. Problems with the tightness of sample bottles were observed. The dispersion of data was larger when samples of running water were taken from the inlet to the bath $(13-15 \%)$ than in cases, when the samples were taken from the reservoir or from the bath (10-11\%).

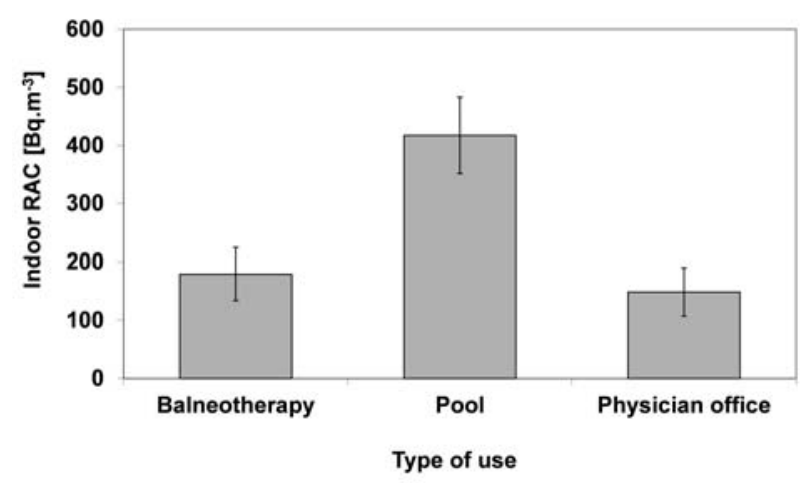

Fig. 2. Comparison of indoor air radon activity concentration among the different types of monitored rooms.

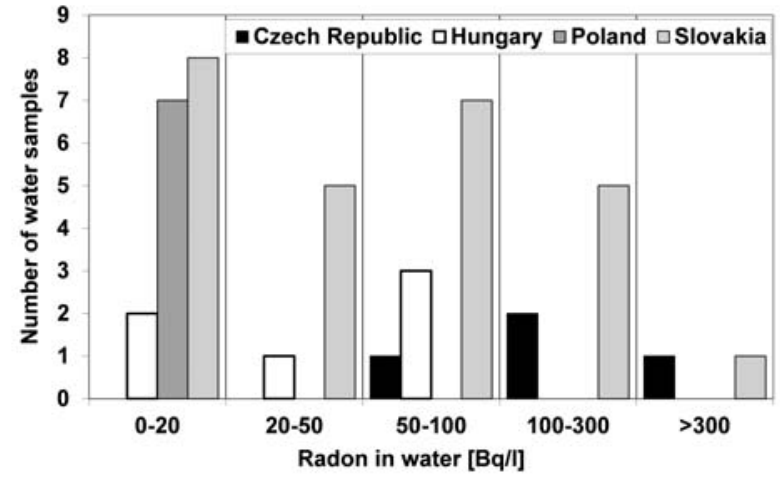

Fig. 3. The frequency distribution of radon in thermal water using in the spas in V4 countries.

Water samples for the assessment of radon activity concentration in thermal waters were collected from the pools, baths, water taps, as well as from the water conduit which directly supplies thermal water to the spa. The number of samples depended on the amount of thermal springs used in balneotherapy. In Fig. 3, the number of water samples according to the value of radon activity concentration in water is shown. Totally were collected 43 samples of thermal waters. The number was different from country to country, for Hungary and Poland 2 samples of water for each spa, for Slovakia and Czech Republic 4 samples of water for each spa were collected, but in one Slovak spa 11 samples of water were collected.

Figure 3 depicts a wide range of measured radon activities. The high radon levels are not generally related to a one specific water source. In one case, increased radon $(373.1 \mathrm{~Bq} / \mathrm{l})$ was found in water collected directly from a borehole; however, in another spa water with similar radon concentration $(383.9 \mathrm{~Bq} / \mathrm{l})$ was found in a water sample collected from a bath. In drinking water samples, collected from the fountains accessible both for patients and spa visitors, radon concentration ranged between 10 and $104 \mathrm{~Bq} / \mathrm{l}$.

Indoor radon activity concentrations in the spas were compared with radon activities measured in water. We were evaluated water samples collected from the taps in baths (Fig. 4a) and water sampled directly from the pools (Fig. 4b), drinking water fountains and springs were not included. The correlation between radon in waters in baths and indoor radon levels was observed $(r=0.78)$.

The less significant influence of radon in pool waters on indoor radon levels was observed $(r=$ 0.51 ), because thermal pool areas were different in size and the amount of water used.

The comparison of radon activity in water samples collected directly from running water from the tap and then from water from the same source in the bath often proved a decrease in radon activity concentration in water taken from the tap. The decrease was caused by the radon release from flowing water. Also the technique how a bath was filled was important. The difference in radon activities was minimal (from 0 to $1 \%$ ) when the bath was filled by the water inlets on the bottom of the bath, not from water taps. In these cases, radon release from water was negligible. In most cases approximately 

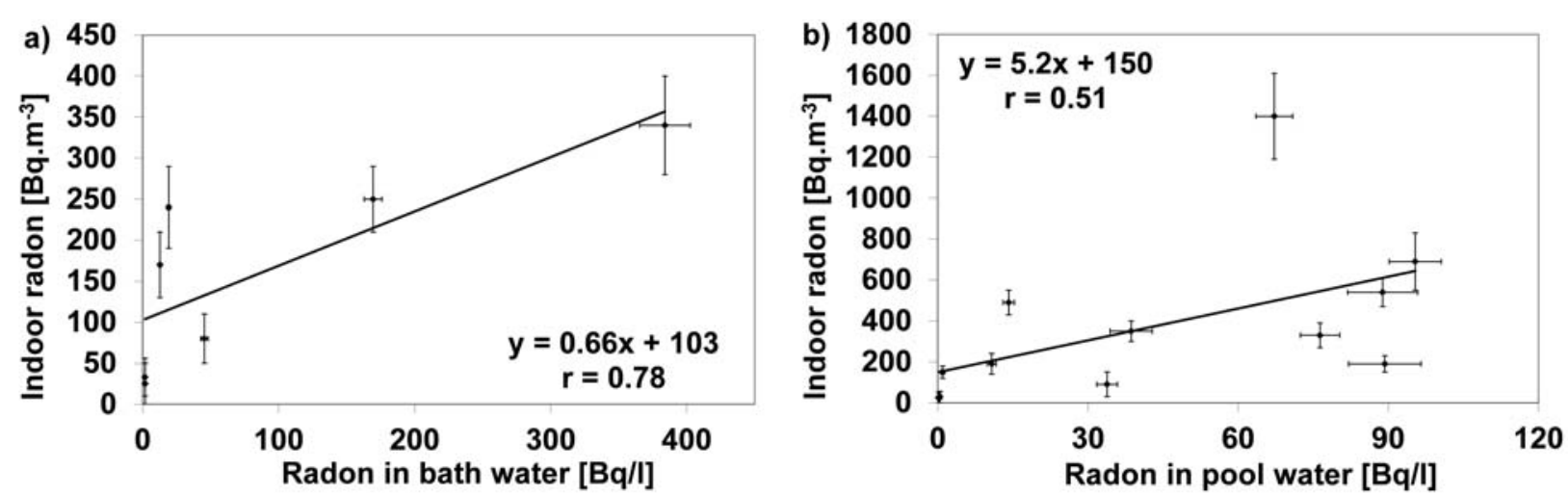

Fig. 4. The dependence of indoor radon and radon in water in spas in V4 countries.

from 34 to $69 \%$ of radon was released from the water when the bath was filled from water taps and it can significantly contribute to the increased radon levels measured in the pool and bath areas of the spa.

\section{Conclusion}

The aims of the radon research were to harmonize the measurements of indoor radon in spas in V4 countries and to find workplaces with possible radon risk. The first results indicate the importance of radon monitoring. The distribution of indoor radon levels in selected spas differed among V4 countries. The highest radon activity concentration was found in rooms close to the pools, where also radon levels exceeding $1000 \mathrm{~Bq} \cdot \mathrm{m}^{-3}$ were measured.

A large interval of radon activities measured in thermal water was observed. In $20.9 \%$ of the water samples radon activity concentration higher than $100 \mathrm{~Bq} / \mathrm{l}$ was found.

The correlation of radon in waters in baths with indoor radon levels was observed. The possible effect of radon activity in the pool water on increased indoor radon levels was ambiguous; also geological settings must be taken into consideration, as well as the construction system of a building. It can be concluded, that thermal water utilization in a balneotherapy did not prove a radiological hazard from this therapeutic method in agreement with the results other authors [6,7].

The technique of bath filling influenced the contribution of radon in the pool and bath areas of the spa. The most increase of indoor radon was observed when the bath was filled from water taps.

Acknowledgments. This work was supported by Visegrad fund no. 21320324: "Radon in thermal waters and radon risk in chosen thermal water spas in V4 countries" and by the Scientific Grant Agency of the Ministry of Education of the Slovak Republic (Vega Project no. 1/0143/14 and Vega Project no. 2/0083/15).

\section{References}

1. Lučivjanský, L., \& Duurecová, A. (2000). Natural radioactivity of mineral waters in Slovakia. In II. Conference on Radioactivity in the Environment, 17-18 May 2000 (pp. 82-86). Spišská Nová Ves, Slovak Republic: Uranpress Ltd. (in Slovak).

2. Koteles, Gy. J. (2007). Radon risk in spas? Cent. Eur. J. Occup. Environ. Med., 13(1), 3-16.

3. Szerbin, P. (1996). Natural radioactivity of certain spas and caves in Hungary. Environ. Int., 22(Suppl. 1), S389-S398.

4. Przylibski, T. A., \& Żebrowski, A. (1999). Origin of radon in medicinal waters of Lądek Zdrój (Sudety Mountains, SW Poland). J. Environ. Radioact., 46, 121-129.

5. Vogiannis, E., Nikolopoulos, D., Louizi, A., \& Halvadakis, C. P. (2004). Radon variations during treatment in thermal spas of Lesvos Island (Greece). J. Environ. Radioact., 75, 159-170. DOI: 10.1016/j. jenvrad.2003.12.002.

6. Radolić, V., Vuković, B., Šmit, G., Stanić, D., \& Planinić, J. (2005). Radon in the spas of Croatia. J. Environ. Radioact., 83, 191-198. DOI: 10.1016/j. jenvrad.2005.02.016.

7. Vaupotič, J., \& Kobal, I. (2001). Radon exposure in Slovenian spas. Radiat. Prot. Dosim., 97(3), 265-270.

8. Nikolov, J., Todorovic, N., Petrovic Pantic, T., Forkapic, S., Mrdja, D., Bikit, I., Krmar, M., \& Veskovic, M. (2012). Exposure to radon in the radon spa Niška Banja, Serbia. Radiat. Meas., 47, 443-450. DOI: 10.1016/j.radmeas.2012.04.006.

9. Gombala, E., Durec, F., Blažekova, M., \& Vičanová, M. (1997). Radon in spa atmosphere of spa in Middle-Slovak region. In 1st Conference on the Radioactivity in the Environment, 21-22 October 1997 (pp. 99-101). Spišská Nová Ves, Slovak Republic: Uranpress Ltd. (in Slovak).

10. Thinova, L., \& Burian, I. (2008). Effective dose assessment for workers in caves in the Czech Republic: Experiments with passive radon detectors. Radiat. Prot. Dosim., 13(1), 48-51. DOI: 10.1093/rpd/ncn118.

11. Neznal, M., Blahušiak, P., Grzadziel, D., Holý, K., Kovács, T., Kozak, K., Mazur, J., Müllerová, M., Nagy, E., Neznal, M., \& Shahrokhi, A. (2014). International intercomparison measurement of radon concentration in water. In 12th International Workshop on the Geological Aspects of Radon Risk Mapping, 16-18 September 2014 (pp. 164-172). Prague, Czech Republic: Czech Geological Survey. 